\title{
REDUCTION OF HYPERCALCIURIA IN TETRAPLEGIA AFTER WEIGHT-BEARING AND STRENGTHENING EXERCISES
}

\author{
By Paul E. Kaplan, M.D., F.A.C.P., Wayne Roden, M.D., \\ Ellen Gilbert, R.P.T., Lois Richards, R.D. and JohN W. GoldSChMIDT, M.D. \\ Rehabilitation Institute of Chicago, 345 East Superior Street, \\ Chicago, Illinois 606I , U.S.A.
}

\begin{abstract}
Both weight-bearing and strengthening exercises have been thought to reduce the hypercalciuria associated with tetraplegia. In patients with incomplete spinal cord injuries and tetraplegia, tilt table exercises reduced hypercalciuria and made the calcium balance more positive particularly in the early group of patients. Strengthening exercises did not have nearly as great an effect.
\end{abstract}

Key words: Tetraplegia; Exercise therapy; Calcium, urine; Spinal cord injuries, rehabilitation.

\section{Introduction}

Tetraplegia has been the clearest example of the effects of immobilisation of large masses of muscle, bone, and joint upon calcium metabolism. Increased urinary levels of calcium and hydroxyproline have been noted in subjects with spinal cord injuries and tetraplegia (Claus-Walker et al., I972; Chantraine, I970-7I). The effects of exercise and weight bearing have been observed to lessen the decrease in bone mass (Guttmann, I953, I97I). Although kinetic studies on calcium metabolism were conducted in this group of subjects, calcium balance studies were not performed. The object of this study was to determine the effect of weight bearing across long bones on calcium metabolism in tetraplegia subjects.

\section{Methods and Materials}

The study group consisted of eight men and two women from I9 to 56 years of age who had spinal cord injuries. The level of injury was determined by a complete neurological examination and was ascertained to be incomplete and between $\mathrm{C}_{5}$ and $\mathrm{C}_{7}$. Six of the subjects were studied within 6 months of the spinal cord injury (early group). Five of the subjects were studied between 12 and I 8 months after the spinal cord injury (late group). None of the subjects had a history of diabetes, kidney disease, or heart disease prior to the spinal cord injury. One of the subjects in the early group had a history of hypertension prior to the spinal cord injury. However, in that subject, the hypertension was not in evidence during the study and required no treatment.

Calcium balances were determined according to the method of Kaplan et al. (1978). In brief, the study consisted of a 3 to 6 day dietary equilibrium period followed by a 3 to 6 day collection period. The diet, supervised by a dietician, contained $100 \mathrm{~g}$ protein and $\mathrm{I} 600 \mathrm{mg}$ calcium daily. Calcium balance studies were performed before and after the start of tilt table exercises (normal urine Calcium $=250 \mathrm{mg} / 24$-hours) for each subject. Each tilt table exercise lasted at least 20 minutes at least once a day, and the tilt table angle attairied was $45^{\circ}$ or greater. The 
exercises were coordinated with the second equilibrium and collection periods. In the early group, calcium balances were determined a third time I week after tilt table exercises had been terminated. Calcium balance values were evaluated using Student's $t$-test or one-way analysis of variance followed by $t$-test. Significance at the I per cent level was chosen (marked with an asterisk ${ }^{\star}$ ).

All of the subjects had manual muscle test serially during the study period and had upper and lower extremity strengthening exercises during the study period. However, none of the subjects was ambulatory.

\section{Results}

Neither sex nor age of the subjects nor protein intake contributed significantly to the results of the calcium metabolic balance studies of this group of subjects. All of the serum calcium, phosphorus, total protein, and albumin values remained within the normal range in both the early and late groups before and after tilt table exercises. All values are expressed as mean and standard error of the mean value.

In all cases, the mean 24-hour urinary calcium output decreased. However, in all but two cases, hypercalciuria persisted. During the initial period of evaluation, prior to tilt table exercises in the early group, the mean faecal calcium excretion was $\mathrm{I} 22 \mathrm{I} \pm 4 \mathrm{mg}$. The mean urinary calcium output was $464 \pm \mathrm{IO} \mathrm{mg}$ and mean calcium balance was $-85 \pm$ I I mg. The mean faecal excretion for the late group, prior to tilt table exercises, was $122 \mathrm{I} \pm 2 \mathrm{mg}$, the mean urinary calcium output $353 \pm \mathrm{I} 6 \mathrm{mg}$, and the mean calcium balance $27 \pm \mathrm{I} 0 \mathrm{mg}$. The total group, prior to tilt table exercises, showed a mean faecal calcium excretion of $122 \mathrm{I} \pm 2 \mathrm{mg}$, a mean urinary calcium value of $410 \pm 28 \mathrm{mg}$, and a mean calcium balance of $58 \pm$ IO mg.

Following tilt table exercises, the early group's mean faecal calcium excretion was I I I I $\pm 4 \mathrm{mg}$, the mean urinary calcium output was $404 \pm 5 \mathrm{mg}$, and the calcium balance was - I $5 \pm 4 \mathrm{mg}^{\star}$. The mean faecal calcium excretion for the late group was $1212 \pm 2 \mathrm{mg}$, the mean urinary calcium output was $323 \pm 28 \mathrm{mg}$, and the mean calcium balance was $55 \pm 10 \mathrm{mg}$. The total group following tilt table exercises showed mean faecal calcium excretion of I II $\pm 3 \mathrm{mg}$, mean urinary calcium output of $366 \pm 27 \mathrm{mg}$, and a mean calcium balance of $34 \pm 9 \mathrm{mg}$.

In the early group, the urinary calcium output decreased after tilt table exercises by $60 \mathrm{mg}$ while the calcium metabolic balance increased by $70 \mathrm{mg}$. In the late group, the urinary calcium output decreased after tilt table exercises by $30 \mathrm{mg}$ while the calcium metabolic balance increased by $28 \mathrm{mg}$.

For the early, late, and early plus late combined groups, there were significant differences between urinary calcium output and calcium metabolic balance before and after tilt table exercises. Prior to tilt table exercises, the difference between the early and late group of urinary calcium output was I I I $\mathrm{mg}^{\star}$ and of calcium metabolic balance was I $2 \mathrm{mg}^{\star}$. After tilt table exercises, the difference of urinary calcium output was $8 \mathrm{I} \mathrm{mg}^{\star}$ and of calcium metabolic balance was $70 \mathrm{mg}$.

For the early group, I week after termination of tilt table exercises, the mean faecal calcium excretion was $1219 \pm 4 \mathrm{mg}$. The mean urinary calcium output was $460 \pm$ I $5 \mathrm{mg}$, and the mean calcium balance was $79 \pm$ I0 $\mathrm{mg}$.

All of the patients in the early group advanced at least one full grade of muscular strength in the upper and lower extremities during the study period. None of the patients of the late group had that amount of augmentation of muscular strength during the study period. 


\section{Discussion}

Change in urinary calcium excretion was noted when duration of the injury was considered. This II I mg difference between the early group (I-6 months) and the late group (I2-I8 months) was consistent with past studies of tetraplegic patients (Claus-Walker et al., 1975, 1977-78). All of the patients in this study had the same level of injury. Associated with the recumbency and the high calcium urinary excretion of the early group was increased bone remodelling and resorption (Heany, 1962). The hypercalciuria was reflected in the composition of urinary tract calculi (Burr, 1972, 1978-79).

Following tilt table exercises, the values for calcium balance and urinary calcium output demonstrated the anticipated changes. In both groups, urinary calcium output decreased. The calcium balance became less negative in the early group and augmented the already positive balance in the late group. In addition, the early group showed a significantly greater response than the late group. The calcium balances in the early group reverted to pre-tilt table levels after the termination of tilt table exercises. Tilt table exercises were a major cause of alteration of the urinary calcium output and calcium balances towards a positive calcium balance and lead to results similar to those noted in paraplegics before and after ambulation (Kaplan et al., 1978).

The lack of hypotension during tilt table exercises would indicate significant residual muscular activity. Certainly, the increased muscular strength seemed to parallel the increased response to tilt table exercises of the early group when compared to the late group. However, the fact that muscular exercise alone has relatively little influence over calciuria was demonstrated by the increase of urinary calcium excretion after the termination of tilt table exercises. Past studies of tetraplegic patients have not differentiated between muscular strengthening and weight bearing exercises with regard to urinary calcium excretion (Claus-Walker et al., 1972, 1977-78). On one hand, voluntary muscle activity inhibited local osteoporosis in hemiplegic patients (Panin et al., 197I) and in animals (Geiser \& Trueta, I958). On the other hand, hypercalciuria has been observed in recumbent patients immobilised by plaster casts (Birge \& Whedon, 1968; Issekutz et al., 1966), after multiple fractures (Scheller \& Crothers, 1979), and by poliomyelitic tetraplegia (Whedon \& Shorr, 1957). However, this new investigation demonstrated that the influence of strengthening exercises was probably less important than that of weight bearing when urinary calcium excretion was considered.

That the calcium excretion increased after the termination of tilt table exercises also indicated that time alone was not a major factor in the decrease of calcium excretion after tilt table exercises. Chantraine (1970-7I) has noted the decrease of calcium excretion with time. However, time minimally influenced the response of the early group of patients to tilt table exercises.

These results are also consistent with the decreased bone density demonstrated in astronauts during the Gemini spaceflights (Hattner \& McMillan, I968). Weight bearing and axial compression seemed to be factors in decreasing the rate at which bone mass was lost. As a result, the National Aeronautics and Space Administration adopted an axial compression exercise programme. This programme led to a reduction in the rate of loss of bone mass in later spaceflights (Birge \& Whedon, I968; Hattner \& McMillan, 1968). These results confirm the importance of axial compression. Moore and Burr (1973) have observed that recumbency removed circadian rhythm of calcium excretion, and the circadian rhythm of parathyroid hormones has been demonstrated (Jubiz et al., 1972). Therefore, the mechanisms 
of the effect of weight bearing upon calcium metabolism was probably hormonal in nature and related to the turnover of parathyroid hormone.

A low calcium diet may also result in a diet low in protein (Talbot, I968). Mobilisation (Birkhead et al., 1966) and tilt table exercises are effective methods of reducing hypercalciuria in the first six months after spinal cord injuries and tetraplegia. The effect of weight-bearing exercises upon calcium metabolism in tetraplegic patients is that of retention and conservation of calcium.

\section{SUMMARY}

The influence of tilt table exercises on the calcium balances of patients with incomplete spinal cord injuries and tetraplegia was examined. Weight bearing across long bones decreased the hypercalciuria. The gain of muscular strength was greater in the early group. The early group had a sharper decrease of hypercalciuria than the late group.

\section{RÉSUMÉ}

L'influence des exercises de la table d'inclinasion sur la balance du calcium des malades souffrant de lesions incomplètes de l'épine cervicale fut examinée. La force du poids a travers les os longs à fait décroître l'excess du calcium dans l'urine. Le gain de la force musculaire etait plus grand dans le groupe tôt. Le groupe tôt ont un décroissement plus tranchant de la hypercalciurie que le groupe tard.

\section{ZUSAMMENFASSUNG}

Der Einfluß von Neigungtischubüngen uber die Calciumwaagschale von Patienten mit unvollstandigen Wirbelsaulen verletzungen und Tetraplegikern werden gebruchen. Die Draft von Gewicht über Langknochen der Ubercalcurin war abnehmt. Der Vorteil von Muskelkraft war in die Zeitiggruppe vermehrt. Die Zeitiggruppe hat em scharfer Verringerung von Übercalcurin als die Spätgruppe gehabt.

Acknowledgement: We are very grateful to Mrs. Mary Barczak for her help in preparing this manuscript. As presented at the 4oth Annual Assembly of the American Academy of Physical Medicine and Rehabilitation, New Orleans, Louisiana, I978.

\section{REFERENCES}

Bergmann, P., Hedpom, A., Schoutens, J., Paternot, J. \& Tricot, A. (1977-78). Longitudinal study of calcium and bone metabolism in paraplegic patients. Paraplegia, I5, I 47 .

BIRGE, S. J., Jr. \& Whedon, G. D. (1968). Bone. In Hypodynamics and hypogravics: Physiology of inactivity and weightlessness. M. McCally, New York, Academic Press, pp. 213-235.

BirkHEAd, N. C., Blizzard, J. J., Issekutz, B., Jr. \& Rodahl, K. (I966). Effect of exercise, standing, negative trunk, and positive skeletal pressure on bed rest induced orthostasis and hypercalciuria. Aerospace Med. Res. Lab. Rep., pp. I-29.

BURR, R. G. (1978-79). A relationship between the composition of the urine and that of urinary tract calculi in spinal patients. Paraplegia, 16, 68.

BURR, R. G. (1972). Urinary calcium, magnesium, crystals, and stones in paraplegia. Paraplegia, 10, 56.

Chantraine, A. (I970-7I). Clinical investigation of bone metabolism in spinal cord lesions. Paraplegia, 8, 253.

Claus-Walker, J., Campos, R. J., Carter, R. E., Vallbona, C. \& Lipscomb, H. S. (I972). Calcium excretion in quadriplegia. Arch. Phys. Med. Rehabil., 53, I4.

Claus-Walker, J., Carter, R. E., Diferrante, N. M. \& Singh, J. (I977-78). Immediate endocrine and metabolic consequences of traumatic quadriplegia in a young woman. Paraplegia, 15, 202. 
Claus-Walker, J., Spencer, W. A., Carter, R. E., Halstead, L. S., Meier III, R. H. \& CAMPOS, R. J. (1975). Bone metabolism in quadriplegia: Dissociation between calciuria and hydroxyprolinuria. Arch. Phys. Med. Rehabil., 56, 327.

Geiser, M. \& Trueta, J. (1958). Muscle action, bone rarefaction, and bone formation: Experimental study. f. Bone foint Surg. (Br), 40, 282.

GutTMAnN, L. (I97I). Principien und methoden en der Behandlung und rehabilitation von Ruckenmarksverletzeten. In Neuro-Traumatologie, Vol. II. L. Guttmann (ed), Urban and Schwarzenberg, Munich, pp. 77-163.

Guttmann, L. (1953). Treatment and rehabilitation of patients with injuries to spinal cord and cauda equina. Surg. Br. Med. History of World War II; London, H.M. Stationery Office, pp. 422-516.

HATtNeR, R. S. \& MCMillan, D. E. (1968). Influences of weightlessness upon skeleton: Review. Aerospace Med., 39, 849.

Heaney, R. P. (I962). Radiocalcium metabolism in disuse osteoporosis in man. Am. $\mathcal{F}$. Med., 33, I $88-200$.

Issekutz, B., Jr., Blizzard, J. J., Birkhead, N. C. \& Rodahl, K. (I966). Effect of prolonged bedrest on urinary calcium output. F. Appl. Physiol., 21, Iог3.

Jubiz, W., Canterbury, J. M., Reiss, E. \& Tyler, F. H., with technical assistance of J. Frailey, K. Bartholomew, and M. A. Creditor (I972). Circadian rhythm in serum parathyroid hormone concentration in human subjects: Correlation with serum calcium, phosphate, albumin, and growth hormone levels. F. Clin. Invest., 5I, 2040.

Kaplan, P. E., Gandhavadi, B., Richards, L. \& Goldschmidt, J. W. (I978). Calcium balance in paraplegic patients: Influence of injury duration and ambulation. Arch. Phys. Med. Rehabil., 59, 447.

Moore Ede, M. C. \& BURR, R. G. (I973). Circadian rhythm of urinary calcium excretion during immobilisation. Aerospace Med., 44, 495.

Panin, N., Gorday, W. J. \& Paul, B. J. (I97I). Osteoporosis in hemiplegia. Stroke, 2, 4I.

SCHELlER, A., Jr. \& CROTHERS, O. (I979). Immobilization hypercalcemia associated with multiple trauma. Orthopedics, 2, 19.

Talbot, H. S. (I968). Adjunctive care of spinal cord injury. Surg. Cl N. Amer., 48, 737.

WHEDON, G. D. \& SHORR, E. (I957). Metabolic studies in paralytic acute anterior poliomyelitis. f. Clin. Invest., 36, 942. 